\title{
ANALISIS SOSIO YURIDIS TERHADAP PENETAPAN ASAL-USUL ANAK PERNIKAHAN SIRIH UNTUK KEPENTINGAN PEMENUHAN HAK ANAK
}

\section{"Socio-Juridical Analysis of The Child Origin Of Betel Marriage Determination For Fulfilment Children's Right"}

\author{
Vitra Fitria M. Koniyo \\ Fakultas Hukum Universitas Negeri Gorontalo, Kota Gorontalo. \\ Korespondensi Email: vkoniyo@gmail.com
}

\begin{abstract}
ABSTRAK
Tujuan penelitian ini adalah untuk mengetahui dan menganalisis penetapan asal usul anak tentang pemenuhan hak anak dari hasil pernikahan sirih yang ditetapkan melalui penetapan pengadilan agama dan untuk mengetahui dan mengenalisis faktor-faktor apa saja yang menghambat penetapan asal usul anak. Metode penelitian ini adalah Penelitian hukum empiris dengan model penelitian yuridis sosiologis yang mempunyai objek kajian mengenai perilaku masyarakat. Adapun dalam pembahasan dan penelitian ini adalah analisis sosio yuridis terhadap penetapan asal usul anak tentang pemenuhan hak anak dari hasil pernikahan sirih ditinjau dari UU Perkawinan. Perkawinan dilakukan secara nikah sirih atau dibawah tangan, maka saat mengajukan pembuatan akta kelahiran anak justru akan ditolak oleh pihak pencatatan sipil dan diarahkan ke KUA dan Pengadilan Agama. Apabila ke Pengadilan Agama, maka jalan keluarnya adalah penetapan asal usul anak. Terkadang anak yang dilahirkan tidak mendapat pengakuan dari sisi hukum. Untuk itu perlu dilakukan adanya penetapan asal usul anak demi memenuhi hak serta kepentingan dari anak tersebut Sedangkan kendala-kendala yang menghambat penetapan asal usul anak yaitu kedua orang tua tersebut tidak mencatatkan pernikahannya karena tidak memiliki buku nikah Dan anak yang dilahirkan saat belum adanya akta cerai secara agama.
\end{abstract}

Kata Kunci: Perkawinan; Anak; Nikah Sirih.

\section{ABSTRACT}

The purpose of this study was to determine and analyze the determination of the origin of children regarding the fulfillment of children's rights from the result of betel marriage which was determined through the ruling of the religious court and to identify and identify the factors that hinder the determination of the child's origin. This research method is empirical legal research with a sociological juridical research model that has the object of study on people's behavior. The discussion and research is a socio-juridical analysis of the determination of the origin of children regarding the fulfillment of children's rights from the results of betel marriage in a review of Article 55 Paragraph 1 No. 1 of 1974 concerning Marriage. Marriage is carried out by betel marriage or under the hands, so when applying for a child's birth certificate it will be rejected by the civil registration and will be directed to both places, namely the KUA and the Religious Court. If you go to the Religious Court, the solution is to determine the origin of the child. Sometimes children who are born do not receive legal recognition. For this reason, it is necessary to determine the origin of the child in order to fulfill the rights and interests of the child.While the obstacles that hinder the determination of the origin of the child are that both parents do not register their marriage because they do not have a marriage book and children born when there is no divorce certificate religion.

Keywords : Marriage; Children; Betelmarriage. 


\section{PENDAHULUAN}

\section{Latar Belakang}

Perkawinan ialah ikatan lahir bathin seorang pria dengan seoraang wanita sebagai suami istri dengan tujuan membentuk keluarga (rumah tangga) yang bahagia dan kekal berdasarkan Ketuhanan Yang Maha Esa sebagaimana diatur dalam Pasal 1 Undang Undang Nomor 16 Tahun 2019 tentang Perkawinan. ${ }^{1}$

Sahnya suatu perkawinan, UndangUndang Nomor 16 Tahun 2019 Tentang Perkawinan telah menetapkan Pasal 2 sebagai patokannya, sebagai berikut :

1. Perkawinan adalah sah, apabila dilakukan menurut hukum masing masing agamanya dan kepercayaanya itu.

2. Tiap - tiap perkawinan dicatat menurut peraturan Perundang - Undangan yang berlaku.

Penjelasan Pasal 2 ayat (1) ini, disebutkan bahwa :

“Dengan perumusan pada Pasal 2 Ayat (1) ini, tidak ada perkawinan di luar hukum masing - masing agamanya dan kepercayaanya itu, sesuai dengan Undang - Undang Dasar 1945. Yang dimaksud dengan hukum masing masing agamanya dan kepercayaanya itu termasuk ketentuan perundang undangan“

Perkawinan dapat dikatakan suatu peristiwa yang paling penting dalam kehidupan masyarakat, karena tidak saja menyangkut pribadi kedua mempelai tapi juga urusan keluarga kedua belah pihak dan juga kehidupan bermasyarakat. ${ }^{2}$

1 Lembaran Negara Republik Indonesia Tahun 1974 Nomor 1, Tambahan Lembaran Negara Republik Indonesia Nomor 301.

2 Dolot Alhasni Bakung. (2014). "Analisis UU No.1 Tahun 1974 Tentang Perkawinan Dan UU No. 23 Tahun 2002 Tentang Perlindungan Anak Terkait Perkawinan Dibawah Umur (Studi Pada Masyarakat Batu Layar
Pernikahan yang belum tercatat di Kantor Urusan Agama (KUA) yaitu Pegawai Pencatat Nikah (PPN), harus melaksanakan Sidang Isbat Nikah, Isbat Nikah merupakan suatu langka bagi pasangan yang belum memiliki akta yang telah melangsungkan perkawinan menurut hukum agama. Namun lantaran statusnya hanya sah secara agama, Pegawai Pencatat Nikah tidak dapat menerbitkan Akta Nikah atas perkawinan siri. Berdasarkan Pasal ayat (2) Kompilasi Hukum Islam (KHI), " Dalam hal perkawinan tidak dapat dibuktikan dengan Akta Nikah, dapat diajukan isbat nikah-nya ke Pengadilan Agama." Di mana penetapan permohonan pengesahan nikah yang diajukan ke pengadilan untuk dinyatakan sah-nya pernikahan dan memiliki kekuatan hukum.

Berdasarkan ketentuan tersebut maka setiap anak berhak untuk mendapatkan perlindungan terhadap haknya. Perlindungan hak terhadap anak disini dilakukan secara universal tanpa pilh - pilih. Hak seorang anak wajib untuk dipenuhi terlepas dari bagaimana status dari anak tersebut. Status seorang anak terbagi atas anak sah dan anak tidak sah ( anak luar kawin ).

Sementara itu, Perkawinan yang dilakukan diluar ketentuan hukum tidak akan mendapat pengakuan dan tidak dilindungi oleh hukum. Tindakan tidak mencatatkan perkawinan, walaupun perkawinan telah dilakukan sesuai dengan ajaran agama Islam, dianggap telah melakukan penyeludupan hukum, alias tidak taat hukum. Suatu perkawinan yang dilaksanakan tidak mematuhi hukum perkawinan tersebut, akan berakibat kepada mereka yang melaksanakan perkawinan tersebut terutama terhadap keturunanya. ${ }^{3}$

Provinsi Gorontalo". Jurnal Vol. 15 No. 1 Januari-Juni: Hal. 16

3 Anshry MK. (2015). Hukum Perkawinan di Indonesi. Yogyakarta : Pustaka Pelajar. Hlm. 45, Lihat juga Nur M. Kasim, (2020). "The Implementation of Modest and Simple Principle To Mahr As A Contribution To The 


\section{Rumusan Masalah}

Berdasarkan

latar

belakang

sebagaimana dijelaskan, maka penulis merumuskan beberapa rumusan masalah yang akan menjadi fokus penelitian sebagai berikut:

1. Bagaimana Analisis Sosio-Yuriddis Terhadap Penetapan Asal Usul Anak Tentang Pemenuhan Hak Anak Dari Hasil Pernikahan Sirih Di Tinjau Dari Pasal 55 Ayat 1 No. 16 Tahun 2019 Perkawinan Di Pengadilan Agama Gorontalo ?

2. Faktor - Faktor Apa Saja Yang Menghambat Penetapan Asal Usul Anak Di Pengadilan Agama Gorontalo?

\section{Metode Penelitian}

Jenis Penelitian yang digunakan oleh peneliti dalam penyusunan penelitian ini jenis penelitian ini adalah penelitian hukum empiris dengan model penelitian yuridis sosiologis mempunyai objek kajian mengenai perilaku masyarakat. Perilaku masyarakat yang dikaji adalah perilaku yang timbul akibat berinteraksi dengan sistem norma yang ada. Interaksi itu muncul sebagai bentuk kreasi masyarakat atas diterapkannya sebuah ketentuan perundangan positif dan bisapulah dilihat dari perilaku masyarakat sebagai bentuk aksi dalam mempengaruhi pembentukan sebuah ketentuan hukum positif. ${ }^{4}$

Adapun pendekatan yang digunakan oleh peneliti dalam menyusun penelitian ini adalah, Bahan hukum primer dalam penelitian ini merupakan bahan yang diperoleh dari Pengadilan Agama Gorontalo, Tentang Penetapan Asal Usul Anak yang dalam penelitian ini merupakan yang menjadi pijakan dalam melakukan tinjauan yang berkaitan dengan bahan yang hendak akan dikaji dalam penelitian ini. bahan utama.

Indonesian Marriage Law. Jurnal Hukum \& Pembangunan, 50 (2), 543
Bahan hukum sekunder merupakan bahan yang memberikan penjelasan mengenai bahan hukum primer. Adapun bahan-bahan sekunder dalam penelitian ini berupa bukubuku/literatur dan dokumen-dokumen lain yang berkaitan dengan masalah yang hendak dibahas dalam penelitian ini.

\section{PEMBAHASAN}

\section{Hak Anak Dari Hasil Pernikahan Sirih}

Anak dari pernikahan sirih. Jika perniikahan tersebut sah dalam syariat, anak dari pernikahan tersebut harusnya juga sah. Tetapi menyangkut keabsahan tersebut belum bisa diakui secara Undang - Undang. Seorang anak yang sah menurut Undang Undang adalah anak hasil dari perkawinan yang sah. Yaitu perkawinan yang tercatat dalam dokumen negara.

Terkait perlindungan atas pemenuhan hak anak dalam perkawinan siri, masih belum bisa terpenuhi sebab anak - anak dari hasil perkawinan siri tersebut mendaptkan imbasnnya yaitu anak - anak tidak memiliki identitas karena UU No. 23 Tahun 2006 tentang Administrasi Kependudukan mensyaratkan pengajuan akta kelahiran harus disertai dokumen perkawinan orang tua yang sah dari negara. Tanpa adanya akta kelahiran maka anak-anak tersebut kesulitan mendaftar sekolah, mendapatkan Kartu Tanda Penduduk (KTP) dan tidak mendapatkan harta warisan. Selain berimbas terhadap administrasi kependudukan juga anak-anak dari hasil perkawinan siri terbebani secara psikologis dan sosial.

Menurut Pasal 42 UU perkawinan, adapun yang dimaksud dengan anak yang sah adalah anak yang dilahirkan dalam atau sebagai akibat perkawinan yang sah; sedangkan mengenai pengertian anak luar kawin tidak di atur secara jelas, namun dari

\footnotetext{
4 Mukti Fajar \& Yulianto Ahmad. (2017). Dualisme Penelitian Hukum Normatif \& Empiris. Yogyakarta: Pustaka Pelajar. Hlm. 51
} 
ketentuan Pasal 42 tersebut berdasarkan Logika Argumentum a Contrario anak yang dilahirkan di luar perkawinan disebut sebagai anak luar kawin.

Di lingkungan masyarakat, anak luar kawin selalu menjadi objek cibiran dan cemoohan, sedangkan si laki-laki yang telah menanam benih yang menyebabkan anak luar kawin ini lahir malah jarang menerima dampak dari perbuatannya, untuk itu, anak luar kawin ini patut mendapatkan perlindungan baik dari segi hukum maupun dari segi Hak Asasi Manusia (HAM).

Ketentuan-ketentuan ini menyangkut hak-hak asasi bagi anak luar kawin di dalam kedudukannya sebagai insan pribadi (Persoon) yang memiliki dimensi khusus dalam kehidupannya. Selain tumbuhkembangnya memerlukan bantuan orang tua, faktor lingkungan juga memiliki peranan yang sangat penting dalam mempengaruhi kepribadia si anak, ketika menyongsong fase kedewasaannya kelak. Anak juga sosok yang akan memikul tanggungjawab di masa yang akan datang, sehingga tidak berlebihan jika negara memberikan perlindungan bagi anakanak dari perlakuan-perlakuan yang dapat menghancurkan masa depannya. Hakekat hukum keperdataan khususnya yang menyangkut status hukum anak luar kawin beserta hak-hak keperdataannya seperti hak waris. Bukan saja memberikan perlindungan kepada anak sah namun anak luar kawin pun sepatutnya diakui keberadaannya, namun di dalam kenyataannya anak luar kawin selalu mendapat perlakuan yang diskriminatif. ${ }^{5}$

Berdasarkan putusan Mahkamah Konstitusi No. 46/PUU-VIII/2010 tanggal 17 Februari 2012, menyatakan, bahwa Pasal 43 Ayat (1) Undang-Undang Nomor 16 Tahun 2019 tentang Perkawinan (Lembaran Negara Republik Indonesia Tahun 2019 Nomor 16, Tambahan Lembaran Negara Republik

5 I Nyoman Sujana. 2015. Kedudukan Hukum Anak Luar Kawin Dalam Perspektif Putusan Mahkamah Konstitusi Nomor 46/PUU-VIII/2010. Yogyakarta: Aswaja Pressindo. Hlm. 45
Indonesia Nomor 3019) yang menyatakan, "Anak yang lahir di luar Perkawinan hanya mempunyai hubungan perdata dengan ibunya dan keluarga ibunya", bertentangan dengan Undang-undang Dasar Negara Republik Indonesia Tahun 1945 sepanjang di maknai menghilangkan hubungan perdata dengan laki-laki yang dapat di buktikan berdasarkan Ilmu Pengetahuan dan Teknologi dan/atau alat bukti lain menurut hukum ternyata mempunyai hubungan darah sebagai ayahnya.

Pasal 43 Ayat (1) Undang-undang Nomor 16 Tahun 2019 tentang Perkawinan (Lembaran Negara Republik Indonesia Tahun 2019 Nomor 16, Tambahan Lembaran Negara Republik Indonesia Nomor 3019) yang menyatakan, "Anak yang dilahirkan di luar perkawinan hanya mempunyai hubungan perdata dengan ibunya dan keluarga ibunya", tidak memiliki kekuatan hukum mengikat sepanjang dimaknai menghilangkan hubungan perdata dengan laki-laki yang dapat dibuktikan berdasarkan ilmu pengetahuan dan teknologi dan/atau alat bukti lain menurut hukum ternyata mempunyai hubungan darah sebagai ayahnya, sehingga ayat tersebut harus di baca, "Anak yang di lahirkan di luar perkawinan mempunyai hubungan perdata dengan ibunya dan keluarga ibunya serta dengan laki-laki sebagai ayahnya yang dapat dibuktikan berdasarkan ilmu pengetahuan dan teknologi dan/atau alat bukti lain menurut hukum mempunyai hubungan darah termasuk hubungan perdata dengan keluarga ayahnya".6

Putusan uji materi Pasal 43 (1) Undang - Undang Nomor 16 Tahun 2019 sesungguhnya ditujukan untuk anak yang lahir diluar perkawinan akibat nikah sirri atau kumpul kebo. Nikah sirri dan kumpul kebo merupakan terminology yang harus dipahami secara berbeda, meskipun dimata hukum

6 Putusan Mahkamah Konstitusi Nomor 46/PUUVIII/2010. HIm. 5 - 6 
keduannya dilakukan tidak sesuai dengan Undang - Undang Nomor 16 Tahun 2019 Tentang Perkawinan. Sedangkan kumpul kebo adalah dua orang laki - laki dan perempuan yang hidup layaknya suami -isteri tanpa diikat oleh perkawinan menurut agama, maupun Negara. Menurut Islam hal tersebut disebut zina dimana adanya hubungan layaknya suami isteri diantara orang yang tidak ada pernikahan yang sah terlepas dari kedua orang tersebut terikat pernikahan dengan orang lain atau tidak. Di sisi lain dalam KUHPerdata anak zina adalah anak yang dilahirkan dari hubungan anatara dua orang laki dan perempuan yang bukan suami isteri dimana salah satu kedua - duanya terikat dalam suatu perkawinan dengan orang lain, dari perbuatan zina tersebut Undang Undang sebagai aturan yang berlaku di Indonesia dan Hukum Islam mengatur mengenai kedudukan dan hubungan nasab anak yang lahir dari pernikahan yang tidak sah maupun zina yaitu dinasabkan kepada ibunya.

Pernikahan di bawah tangan termasuk salah satu perbuatan hukum yang bertentangan dengan Undang - Undang karena terdapat kecendurungan kuat dari segi sejarah hukum perkawinan bahwa perkawinan dibawah tangan termasuk perkawinan illegal. Walaupun demikian dalam Pasal 5 ayat 1 Kompilasi Hukum Islam terdapat informasi implicit bahwa pencatatan perkawinan bukan sebagai syarat sah perkawinan, melainkan alat untuk menciptakan ketertiban perkawinan.

Dalam keputusan ijtima ulama Komisi Fatwa Se-Indonesia terdapat ketentuan fatwa terkait nikah dibawah tangan.

1. Nikah di bawah tangan yang dimakud dalam fatwa ini adalah pernikahan yang terpenuhi semua rukun dan syarat yang ditetapkan dalam Hukum Islam namun

7 Jaih Mubarok. (2015). Pembaruan Hukum Perkawinan Di Indonesia. Bandung : Simbiosa Rekatama Media. Hlm. 77-78 tanpa pencatatan resmi sebagaimana diatur oleh peraturan Perundang Undangan;

2. Pernikahan seperti itu dipandang tidak memenuhi ketentuan peraturan Perundang - Undangan dan kerap kali menimbulkan dampak negative terhadap isteri ataupun anak yang dilahirkannya terkait dengan hak - hak mereka. $^{7}$

3. Peserta ijtima ulama sepakat bahwa pernikahan harus dicatatkan secara resmi pada instansi berwenang sebagai langkah preventif untuk menolak dampak negative / mudarat;

\section{Pernikahan dibawah tangan} hukumannya sah karena telah terpenuhinya syarat dan rukun nikah tetapi haram jika tidak terdapat mudarat. ${ }^{8}$

Seorang anak dikategorikan sebagai anak sah menurut Undang - Undang perkawinan jika dilahirkan dalam atau sebagai akibat dari perkawinan yang sah. Ada dua kategori yang dirumuskan Undang Undang untuk menunjuk keabsahan seorang anak, yaitu berdasarkan waktu kelahirannya dan sebab yang mengaitkan tumbuhnya anak di dalam rahim seorang perempuan sebagai akibat dari perkawinan yang sah. Jika dibandingkan dengan ketentuan Pasal 250 KUHPerdata yang berbunyi tiap - tiap anak yang dilahirkannya atau ditumbuhkan sepanjang perkawinan memperoleh si suami sebagai bapaknnya. Maka subtansi pengertian keduannya memiliki sedikit perbedaan karena ketentuan Pasal 250 KUHPerdata lebih meningkankan keabsahan anak semata - mata hanya pada hubungan kebapakan. Menurut DY Witanto beberapa faktor yang melatarbelakangi kahamilan pranikah dan kelahiran anak luar kawin antara lain :

8 Jaih Mubarok. (2015). Pembaruan Hukum Perkawinan Di Indonesia. Bandung : Simbiosa Rekatama Media. HIm. 77-78 
1. Usia pelaku masih dibawah batas usia yang diizinkan untuk melangsungkan pernikahan;

2. Belum siap secara ekonomi untuk melangsungkan perkawinan;

3. Perbedaan keyakinan dan kepercayaan (agama);

4. Tidak mendapat restu orang tua;

5. Laki - laki terikat perkawinan dengan wanita lain dan tidak mendapat izin untuk melakukan poligami;

6. Pergaulan seks bebas. ${ }^{9}$

Mereka berpendapat bahwa pencatatan perkawinan adalah syarat sah sebuah perkawinan. Oleh karena itu perkawinan yang tidak di catat (perkawinan bawah tangan) dianggap tidak mempunyai kekuatan hukum. ${ }^{10}$

Kecendurungan menjadikan pencatatan perkawinan sebagai salah satu syarat perkawinan dipertegas lagi dalam peraturan Pemerintah Nomor 9 Tahun 1975 Tentang Pelaksanaan Undang-Undang Nomor 16 Tahun 2019 tentang Perkawinan. Dalam PP Nomor 9 Tahun 1975 ditetapkan bahwa:

1. Pencatatan perkawinan yang dilakukan menurut agama islam dilakukan oleh pegawai pencatat nikah;

2. Setiap yang akan melangsungkan perkawinan memberitahukan kehendaknnya kepada Pegawai Pencatat Nikah di tempat perkawinan akan dilangsungkan sekurang kurangnya sepuluh hari kerja sebelum perkawinan dilangsungkan. Pemberitahuan dapat dilakukan secara lisan ataupun tertulis oleh orang yang bersangkutan, orangtua atau wakilnya;

3. Perkawinan dilaksanakan dihadapan Pegawai Pencatat Nikah dan dihadiri oleh dua orang saksi. ${ }^{11}$

Menyangkut pencatatan perkawinan diperlukan kajian lebih mendalam dengan

${ }^{9}$ Op. Cit, Siska Lis Sulistiani, Hal 11.

10 Ibid. Hlm. 20-21

11 Op.Cit. Jaih Mubarok, Hlm. 67 terbitnya Undang - Undang Republik Indonesia Nomor 24 Tahun 2013 segala pencatatan peristiwa penting dari tata kehidupan seseorang misalnya kelahiran maupun kematian oleh pemerintah mulai dilakukan pembenahan sesuai dengan tuntutan kebutuhan zaman. ${ }^{12}$

Memang harus diakui dalam menyikapi keberadaan " kawin siri " yang sering terjadi dalam masyarakat menyangkut keabsahannya. Keabsahan suatu perkawinan akan menentukan kedudukan hukum anak yang dilahirkan. Manakala perkawinan itu sah, maka anak yang dilahirkan dari perkawinan tersebut akan memperoleh kedudukan hukum sebagai anak sah seperti yang ditetapkan oleh Pasal 42 Undang Undang Perkawinan. Sebaliknya kalau ada perkawinan tersebut tidak menduduki posisi sebagai anak sah. Akibat lanjutnya anak yang dilahirkan diluar perkawinan hanya mempunyai hubungan keperdataan dengan ibunya dan keluarga ibunnya saja. Sungguh dilematis menyikapi keberadaan anak yang dilahirkan diluar perkawinan ini dan perihal tersebut terbuktikan bahwa pemerintah sendiri sampai beberapa decade berlalu bahkan setengah abad lebih tak kunjung menebitkan peraturan yang dijanjikannya karena gamang. Harus diakui memang sulit menentukan anak luar kawin yang bersangkutan secara tegas, karena kentallnya unsure agamawi menyelimuti Undang Undang Perkawinan. Kelahiran anak luar kawin tidak dapat ditimpakkan keselahan kepadannya karena itu semua adalah ulah pasangan yang telah melakukan hubungan seksual diluar perkawinan ataupun sebagai akibat suatu perkawinan yang tidak sah.

Penetapan asal usul anak dalam perspektif hukum Islam memiliki arti yang sangat penting, karena dengan penetapan itulah dapat diketahui hubungan mahram

12 H. Moch. Isnaeni. (2016). Hukum Perkawinan Indonesia. Bandun : PT. Refika Aditama. Hlm. 40 
(nasab) antara anak dengan ayahnnya. Kendatipun pada hakikatnnya setiap anak yang lahir berasal dari sperma seorang lakilaki sejatinnya harus menjadi ayahnnya, namun Hukum Islam memberikan ketentuan lain, seorang anak dapat dikatakan sah jika memiliki hubungan nasab dengan ayahnya jika terlahir dari perkawinan yang sah. Sebaliknnya anak yang lahir diluar perkawinan yang sah, tidak dapat disebut dengan anak yang sah, biasa disebut dengan anak zina atau anak diluar perkawinan yang sah, dan ia hanya mempunyai hubungan nasab dengan ibunnya. Sedangkan berkenaan dengan pembuktian asal usul anak di dalam Undang - Undang Nomor 16 Tahun 2019 diatur dalam Pasal 55 Yang berbunyi sebagai berikut :

(1) Asal usul seorang anak dapat dibuktikan dengan akta kelahiran autentik yang dikeluarkan oleh pejabat yang berwenang;

(2) Bila akta tersebut dalam ayat (1) Pasal ini tidak ada, maka Pengadilan dapat mengeluarkan penetapan asal usul anak seorang anak setelah diadakan pemeriksaan yang teliti berdasarkan bukti - bukti yang memenuhi syarat;

(3) Atas dasar ketentuan Pengadilan tersebut ayat (2) Pasal ini, maka instansi pencatat kelahiran yang ada dalam daerah hukum Pengadilan yang bersangkutan mengeluarkan akta kelahiran bagi anak yang bersangkutan.

\section{Faktor Penghambat Penetapan Asal Usul Anak di Pengadilan Agama Gorontalo}

Berdasarkan hasil penelitian yang telah penulis lakukan, terdapat beberapa faktor yang menghambat penetapan asal usul anak di pengadilan agama Gorontalo. Diantaranya yaitu:

1. Tidak Diadakan Persyaratan Tes DNA. Aturan sebenarnya di Pengadilan Agama Gorontalo harus mempunyai TES DNA, tetapi dipengadilan tidak diadakan karena mereka memakai asas sederhana dan cepat biar ringan. Karena TES DNA harus ke Makassar dan terlalu banyak biayanya. Maka untuk menunjang TES DNA tersebut hanya dari saksi. Dimana aturan 283Rbg semua permohonan harus ada bukti dan saksi. Jika mereka memakai TES DNA perkara akan sangat lama. Dan semakin lama anak tersebut akan menganggur sekolah karena prosedur masuk sekolah di tahun 2019 harus mempunyai akta kelahiran.

2. Tidak Mempunyai Buku Nikah.

Mengenai buku nikah, pihak orang tua tidak melakukan pencatatan perkawinan karena hanya menikah sirih, maka dari pernikahan sirih tersebut mengakibatkan anak tidak mendapatkan akta kelahiran. Karena prosedur dalam mengurus akta kelahiran harus mempunyai buku nikah, sedangkan di kota Gorontalo ini banyak yang menikah sirih dan tidak memikirkan kedepannya nanti, dan imbasnya kepada anak yang tidak mengetahui soal pernikahan tersebut.

3. Tidak Adanya Saksi

Untuk keterangan saksi terkadang mereka tidak hadir dalam persidangan tersebut dan itu bisa memperlambat putusan majelis untuk penetapan asal usul anak di pengadilan agama Gorontalo.

4. Anak Yang Di Lahirkan Saat Belum Adanya Akta Cerai.

Banyaknya perkawinan siri yang belum cerai dengan istri sebelumnya maka hal ini sangat menghambat prosedur untuk memenuhi penetapan asal usul anak, karena salah satu dari sepasang tersebut belum bercerai dengan istri lamanya, walaupun mereka sudah tidak tinggal serumah tetap saja ketidakadaan akta cerai menjadi kesulitan untuk mengurus akta kelahiran anak tersebut.

Kelahirannya tidak tercatatkan, maka anak-anak dari perkawinan siri tidak mempunyai identitas resmi di hadapan 
hukum Negara. Imbasnya anak tidak memiliki identitas karena UU No. 23 Tahun 2006 tentang Administrasi Kependudukan mensyaratkan pengajuan akta kelahiran harus disertai dokumen perkawinan orang tua yang sah dari negara. Tanpa adanya akta kelahiran maka anak-anak tersebut kesulitan mendaftar sekolah, mendapatkan Kartu Tanda Penduduk (KTP) dan tidak mendapatkan harta warisan. ${ }^{13}$

\section{PENUTUP}

\section{Kesimpulan}

Berdasarkan hasil penelitian, peneliti dapat menyimpulkan bahwa hasil dari penelitian ini menunjukan:

Pertama, bahwa perlindungan atas pemenuhan hak anak dalam perkawinan siri di Gorontalo, masih belum bisa terpenuhi sebab anak-anak dari hasil perkawinan siri tersebut mendaptkan imbasnnya yaitu anakanak tidak memiliki identitas karena UU tentang Administrasi Kependudukan mensyaratkan pengajuan akta kelahiran harus disertai dokumen perkawinan orang tua yang sah dari negara.

Kedua, bahwa factor penghambat penetapan asal usul anak yaitu, apabila wali nikah tidak berhak memberikan wali, maka pasangan yang bersangkutan terhitung menikah tidak sah secara agama maupun hukum positif.

\section{Referensi}

\section{Buku:}

Ahmad Kamil. 2010. Hukum Perlindungan Dan Pengangkatan Anak DiIndonesia. Jakarta: PT.RajaGrafindo.

Amirudin \& Zainal Asikin. 2014. Pengantar Metode Penelitian Hukum . Jakarta: Rajawali Pers.

Anshry MK. 2015. Hukum Perkawinan di Indonesia . Yogyakarta : Pustaka Pelajar.
Bambang Daru Nugroho. 2017. Hukum Perdata Indonesia Integrasi Hukum Eropa Kontinental Ke Dalam Sistem Hukum Adat dan Nasional. Bandung: PT Refika Aditama.

H. Moch. Isnaeni. 2016. Hukum Perkawinan Indonesia . Bandung : PT. Refika Aditama.

I Nyoman Sujana. 2015. Kedudukan Hukum Anak Luar Kawin Dalam Perspektif Putusan Mahkamah Konstitusi Nomor 46/PUU-VIII/2010. Yogyakarta: Aswaja Pressindo.

Jaih Mubarok. 2015. Pembaruan Hukum Perkawinan Di Indonesia. Bandung : Simbiosa Rekatama Media.

M.ran Suadi. 2016. Majalah Peradilan Agama. (Perlindungan Hak-Hak Anak Di Peradilan Agama) .

Mukti Fajar \& Yulianto Ahmad. 2017. Dualisme Penelitian Hukum Normatif \& Empiris. Yogyakarta: Pustaka Pelajar.

Maidin Guitom. 2014. Perlindungan Hukum

Terhadap Anak Dan Perempuan.

Bandung: Refika Aditama.

M. Anshary. 2015. Hukum Perkawinan Indonesia. (masalah - masalah krusial). Jakarta: Pustaka Pelajar.

Liza Agnesta Krisna. 2018. Hukum Perlindungan Anak Panduan Memahami Anak Yang Berkonflik Dengan Hukum. Yogyakarta: Deepublish.

Nur Moh. Kasim. 2014. Hukum Islam Dan Masalah Kontemporer. Yogyakarta.

Nur M. Kasim, (2020). “The Implementation of Modest and Simple Principle To Mahr As A Contribution To The Indonesian Marriage Law. Jurnal Hukum \& Pembangunan, 50 (2), 543

Salim HS. 2011. Pengantar Hukum Perdata Tertulis (BW). Jakarta: Sinar Grafika.

Siska Lis Sulistiani. 2015. Kedudukan Hukum Anak. Bandung: PT Refika Aditama. 
Taufiqurrohman Syahuri . 2013. Legilasi Hukum Perkawinan Indonesia. Jakarta: Kencana.

Zainuddin Ali. 2012. Hukum Perdata Islam Di Indonesia. Jakarta: Sinar Grafika.

Undang - Undang :

Undang-Undang Tahun 1974 Tentang Perkawinan

Pasal 14 Kompilasi Hukum Islam

Jurnal:

Kamalayati Fatia - Pursetyowati Sri. 2016. Kedudukan Anak Hasil Pernikahan Siri . Media. Neliti. com. 19 juli 2020.
Bakung, Alhasni Dolot. 2014. Analisis UU No. 1 Tahun $1974 \quad$ Tentang Perkawinan dan UU No. 23 Tahun 2002 Tentang Perlindungan Anak Terkait Perkawinan Di Bawah Umur (Studi Pada Masyarakat Batu Layar Provinsi Gorontalo. Jurnal Al Hurriya: Jurnal Hukum Islam, Vol. 15 Nomor I.

Tomu, H Ismail. 2010. Perkawinan Di Bawah Tangan Menurut Hukum Islam dan Pengaruhnya Terhadap Anak. Jurnal Legalitas, Vol. 3 Nomor II. 